\title{
Polyarteritis nodosa presenting with renal hematoma
}

\author{
Rollino $C^{1 *}$, Imarisio $M^{2}$, Beltrame $G^{1}$, Ferro $M^{1}$, Fenoglio $R^{1}$, Quattrocchio $G^{1}$, Del Vecchio $G^{1}$, Murgia $S^{1}$ and Roccatello $D^{1}$ \\ ${ }^{1}$ Department of Nephrology and Dialysis, Research Center of Clinical Immunology and Immunopathology and Documentation on Rare Diseases (CMID), S. \\ Giovanni Bosco Hospital, University of Turin, Italy \\ ${ }^{2}$ Department of Radiology, S. Giovanni Bosco Hospital, Italy
}

\section{Introduction}

Polyarteritis nodosa (PAN) is an infrequent arteritis involving medium-sized vessels. It is known to be associated to hepatitis $B$ virus infection. It often determines renal function impairment, but urinary signs are slight due to the prevalent ischemic renal damage.

\section{Case report}

A 48-year-old Romanian man presented to the Emergency Department because of intense left loin pain with neither fever nor hematuria. He reported impaired deambulation in the previous weeks.

Laboratory examinations showed hemoglobin $6 \mathrm{~g} / \mathrm{dl}$, Serum creatinine (SCr) $2.8 \mathrm{mg} / \mathrm{dl}$, sodium $140 \mathrm{mEq} / \mathrm{l}$, potassium $5.2 \mathrm{mEq} / \mathrm{l}$, leukocytes $17410 / \mathrm{mm}^{3}$, platelets $92.000 / \mathrm{mm}^{3}$, normal coagulation parameters, C Reactive Protein $17.5 \mathrm{mg} / \mathrm{dl}$. Urine test was normal. Ultrasound (US) showed left perirenal hematoma.

Due to intense pain and the abnormal US finding, CT was performed which in the angiographic phase showed a $2 \mathrm{~cm}$ left subcapsular renal hematoma. Rosary bead-like renal arteries pattern suggested diffuse bilateral microaneurysms (Figure 1). Multiple hypodensity areas of the renal parenchyma were also evidenced.

Arteriography confirmed these features (Figures 2 and 3), showing multiple, disseminated microaneurysms of interlobar arteries. Diagnosis of PAN was made. The hypodense areas at CT were attributed to renal infarctions, the perirenal hematoma to rupture of microaneurysms, as there were no signs of ongoing bleeding no embolization was performed.

Other examinations revealed: bicarbonate $17.7 \mathrm{mmol} / \mathrm{L}$, calcium $2.2 \mathrm{mmol} / \mathrm{L}$, phosphate $8.4 \mathrm{mg} / \mathrm{dl}$, PTH $67 \mathrm{pg} / \mathrm{mL}$, total proteins 4.7 $\mathrm{g} / \mathrm{dl}$ (albumin $63.4 \%$, alfa 1 globulins $5.1 \%$, alfa 2 globulins $8.4 \%$, beta globulins $9.3 \%$, gamma globulins $13.8 \%$ ), albumin $2.2 \mathrm{~g} / \mathrm{dl}$, glucose 74 $\mathrm{mg} / \mathrm{dl}$, uric acid $5 \mathrm{mg} / \mathrm{dl}$, LDH $812 \mathrm{U} / \mathrm{l}$, AST $40 \mathrm{U} / \mathrm{l}$, ALT $42 \mathrm{U} / \mathrm{l}$, gamma GT $94 \mathrm{U} / \mathrm{l}$, alkaline phosphatase $101 \mathrm{U} / \mathrm{l}$, bilirubin $0.6 \mathrm{mg} / \mathrm{dl}$, amilase $150 \mathrm{U} / \mathrm{l}$, sideraemia $55 \mathrm{mcg} / \mathrm{dl}$, ferritin $1285 \mathrm{ng} / \mathrm{ml}$, TSH $0.78 \mathrm{mcUI} / \mathrm{m}$, occult blood test negative. Proteinuria was $260 \mathrm{mg} /$ day, urinary sediment was irrelevant. C3 was $68 \mathrm{mg} / \mathrm{dl}$, C4 $15 \mathrm{mg} / \mathrm{dl}$, IgA $361 \mathrm{mg} /$ dl, IgG 2206 mg/dl, IgM 86 mg/dl, ESR 105 mm/h, haptoglobin 215 $\mathrm{mg} / \mathrm{dl}$; anti-DNA, ANA, c- and p-ANCA were negative. Cryoglobulins were absent.

Hepatitis C and HIV screening was negative. Hepatitis B antigen was positive, and HBV-DNA showed high viral replication (170x106 copies/mL; HBV: A genotype).

CT of thorax and brain were regular.
Electromyography showed signs of severe multiplex motor neuropathy.

The patient was treated with $6 \times 250 \mathrm{mg}$ corticosteroid pulses, $4 \times 400$ $\mathrm{mg} / \mathrm{kg}$ i.v. immunoglobulins, oral cyclophosphamide $50 \mathrm{mg} /$ day for 5 days, $4 \times 375 \mathrm{mg} / \mathrm{mq}$ rituximab and entecavir $0.5 \mathrm{mg} /$ day. Moreover, he was given ramipril $5 \mathrm{mg} /$ day, nifedipine $20 \mathrm{mg}$ /day, furosemide 500 $\mathrm{mg} /$ day, calcium carbonate $1 \mathrm{~g} /$ day, nebivolol $5 \mathrm{mg} /$ day, pantoprazole $20 \mathrm{mg} /$ day, doxazosin $4 \mathrm{mg} /$ day, zeta Epoetin $4000 \mathrm{U} 3$ times/week, and, when an active Cytomegalovirus infection was found, valganciclovir.

In spite of the treatment, the renal function progressively worsened, and the patient reached end stage renal disease after 20 days. Dialysis was started, and renal function did not recover.

\section{Discussion}

PAN is a systemic necrotizing vasculitis that typically affects medium-sized arteries, with occasional involvement of small arteries [1]. It is a rare disease as its frequency is estimated to be 4.4 to 9.7 per million [2].

Thickening and intimal proliferation of the inflamed vessels can cause ischemia and weaken vessel walls, leading to the formation of aneurysms [1].

A mononeuropathy multiplex is one of the most common findings, occurring in up to 70 percent of patients [3], and in autopsy studies the kidneys are the most commonly involved organ [3].

The disease is not usually associated with antineutrophil cytoplasmic antibodies (ANCA) positivity. Hepatitis B virus infection may be a triggering factor [3].

Our patients presented areas of kidney infarction secondary to ischemic damage and a perirenal hematoma that was probably due to a rupture of some mycroaneurysms, similar to what has already been reported in the liver [4].

The recent introduction of Rituximab in the induction phase of vasculitis treatment has been found very effective and has allowed to reduce the rate of immunosuppressive drugs [5].

${ }^{*}$ Correspondence to: Cristiana Rollino, Department of Nephrology and Dialysis, Research Center of Clinical Immunology and Immunopathology and Documentation on Rare Diseases (CMID), S. Giovanni Bosco Hospital, University of Turin, Italy, Tel: 390112402335; Fax: 390112402386; E-mail: cristiana.rollino@libero.it

Received: September 18, 2018; Accepted: September 26, 2018; Published: September 28, 2018 


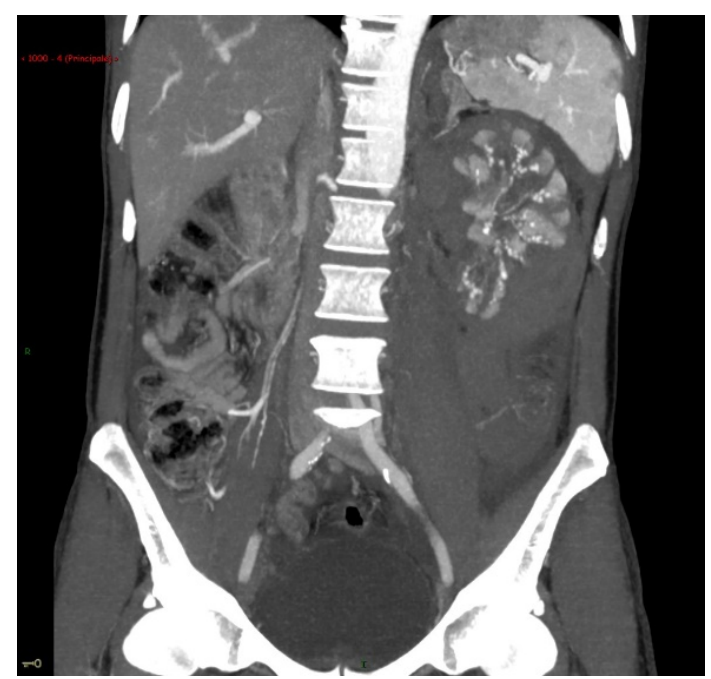

Figure 1. CT scan shows multiple images of microaneurysms in the left kidney and a perirenal hematoma

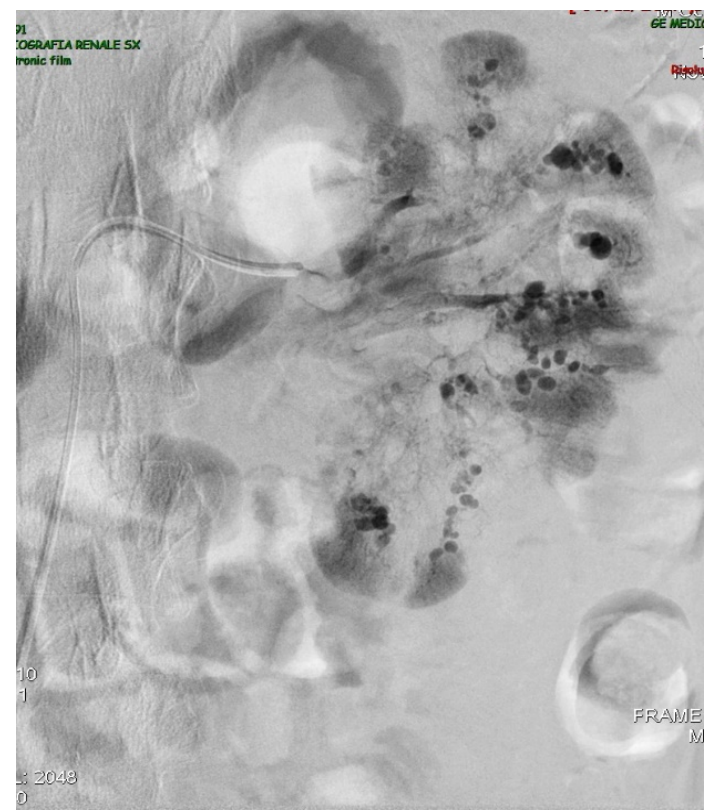

Figure 3. Arteriography. Multiple aneurysms in the left kidney. The distribution of contrast medium is dyshomogeneous and multiple avascular/ischemic areas are evident

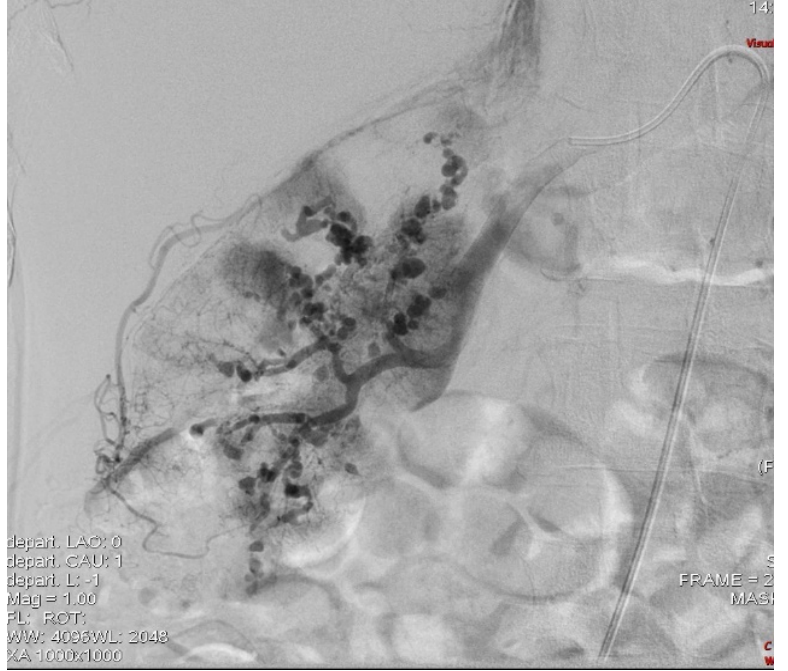

Figure 2. Arteriography. Multiple aneurysms in the right kidney. The distribution of contrast medium is dyshomogeneous and multiple avascular/ischemic areas are evident.

In our patient corticosteroids and cyclophosphamide were given cautiously because of the very high rate or hepatitis B viral replication. However, the treatment was ineffective on renal outcome. Moreover, the patient developed a severe and invalidating neuropathy.

\section{Conclusion}

In conclusion PAN still remains a threatening disease in which late onset and late treatment may lead to loss of vital functions or death.

\section{References}

1. Guillevin L, Mahr A, Callard P, Godmer P, Pagnoux C, et al. (2005) Hepatitis B virus-associated polyarteritis nodosa: clinical characteristics, outcome, and impact of treatment in 115 patients. Medicine (Baltimore) 84: 313-322. [Crossref]

2. Watts RA, Gonzalez-Gay MA, Lane SE, Garcia-Porrua C, Bentham G, et al. (2001) Geoepidemiology of systemic vasculitis: comparison of the incidence in two regions of Europe. Ann Rheum Dis 60: 170-172. [Crossref]

3. https://www.uptodate.com/contents/clinical-manifestations-and-diagnosis-ofpolyarteritis-nodosa-in-adults

4. Wicherts DA, Bruntink MM, Demirkiran A, van Santvoort HC, van Lienden KP, et al. (2015) Ruptured hepatic artery aneurysm: an unusual presentation of polyarteritis nodosa. BMJ Case Rep 2015: 208240.

5. Yates M, Watts RA, Bajema IM, Cid MC, Crestani B, et al. (2016) EULAR/ERAEDTA recommendations for the management of ANCA-associated vasculitis. Ann Rheum Dis 75: 1583-1594. [Crossref]

Copyright: (C2018 Rollino C. This is an open-access article distributed under the terms of the Creative Commons Attribution License, which permits unrestricted use, distribution, and reproduction in any medium, provided the original author and source are credited. 